\title{
Factors Influencing Job Stress Among Malaysian Traffic Police Officers
}

\author{
Muhamad Khalil Omar ${ }^{1}$, Ainie Hairianie Aluwi ${ }^{1}$, Norashikin Hussein ${ }^{1}$, Idaya Husna Mohd ${ }^{1} \&$ Syezreen Dalina \\ Rusdi $^{1}$ \\ ${ }^{1}$ Faculty of Business and Management, Universiti Teknologi MARA, Cawangan Selangor, Bandar Puncak Alam, \\ Selangor, Malaysia \\ Correspondence: Muhamad Khalil Omar, Faculty of Business and Management, Universiti Teknologi MARA, \\ Cawangan Selangor, Bandar Puncak Alam, Selangor, Malaysia. E-mail: khalil.omar@uitm.edu.my
}

Received: May 12, 2020

Accepted: June 20, 2020

Online Published: June 29, 2020

doi:10.5430/ijfr.v11n3p155

URL: https://doi.org/10.5430/ijfr.v11n3p155

\begin{abstract}
Traffic police officers face many challenges in their line of duty to the protect the country and its citizens. Despite, the significance of traffic police officers to the community and the country, lack of studies specifically on how workload, reward system, and work-life balance affects job stress among traffic police officers are apparent. Job stress is the harmful physical and emotional responses that occur. when the requirements of the job do not match the capabilities, resources, or needs of the worker. Job stress creates tension in the working environment, and this research aims to solve and find out what is the cause for job stress either workload, work-life balance or reward system. The observational was finished by utilizing a poll and questionnaires as a measuring instrument. The questionnaires were composed based on the literature review and have inquiries and things significant to the underlying research issues by using five-point Likert scale type questions. Survey data were gathered from questionnaires distributed to 300 respondents at a Traffic Police Office in Kuala Lumpur, Malaysia. A total of 100 returned questionnaires were used in statistical analysis. The results of multiple regression analysis indicated that the relationship between work-life balance and job stress as the significant factor causing stress among Malaysian traffic police officers while there were no significant relationships between workload, reward system, and job stress. Therefore, the traffic police management need to look into the work-life balance initiatives such as flexi-time work arrangements and leave policies to reduce the stress among its staff.
\end{abstract}

Keywords: job stress, reward system, workload, work-life balance

\section{Introduction}

Traffic police faces many job-related challenges in crime fighting and protection of the country from threat and danger. The basic job functions of a traffic police are traffic control, enforcement and dignitaries escort. Traffic police faces complaints from civilians in the course of enforcement and traffic control. Traffic policeman's work as a traffic controller normally runs during peak traffic hours ( $6 \mathrm{am}$ to $10 \mathrm{am}$ and $4 \mathrm{pm}$ to $7 \mathrm{pm}$ ). Traffic policemen are responsible to ensure that all main roads are clear from traffic and this includes clearing road barriers, acting upon distress call from accidents, car breakdowns, and major road accidents that involves hurt or dying individuals. Hence, traffic policeman ensures that the road is clear to make way for ambulance and help etc. In addition, their line of duty also involves providing or escorting VVIPs (very important people) to their destinations which surrounds ministers not only from local but foreign as well. Therefore, police work was one of the most stressful occupations (Noblet, Rodwell, \& Allisey, 2009). "Workplace stress" is the harmful physical and emotional responses that can happen when there is a conflict between job demands on the employee and the amount of control an employee has over meeting these demands (Violanti et al., 2017). Excessive workload is a source of stress at work and emotional exhaustion. Workload of a traffic police can be seen whereby he/she operates full time with a small number of officers on duty. Higher demands at work drain precious resources such as time, energy and emotions, which are essential to fulfill family obligations. Sometimes the police traffic workload often involves unexpected escorts which require police staff has to be on standby mode all day long until our work is done, and our service is no longer needed. However, traffic police staff would not know when the duty should end since it relies on the VVIPs escorted. This would ultimately lead to stress.

Stress doesn't necessarily come from workload alone, but other factor such as balance between work and life or work-life balance can cause stress. Previous research suggests that job situation and an imbalance between work and family roles can be the cause of stress (Allisey, Rodwell, \& Noblet, 2016). Sometime due to nature of work itself that caused an imbalance between work and family roles would tarnish the relationship between spouse/family and this 
ultimately causing stress. For example, the working hours of traffic police officers change all the time. Sometimes they were tasked for an 8 hour duties, sometimes for up till 12 hours' duties and these duties are not planned ahead and they were made known of the task only a day earlier. This often interferes with the police officer's planned family activities. In addition, police staff also must work during weekends and rarely get time off duty which would limit their time spent with their spouses, children and families. Even if they apply for leave before planning their family trip, notice of leave freeze are often in effect without any warning. Hence, this is very common at the traffic police department because of people rallying, during election period and such as ad-hoc election whenever a parliament member has passed away.

Other major factors that cause stress at a workplace are lack of recognition from superiors, colleagues and rewards. For example, there is no age limit to be in certain grade or rank within the traffic police force. You could start off as a recruit (with only secondary school education) and you could retire as a lance corporal at the age of 60 years old (you move from recruit to trainer then to constable and lance corporal). This would take the traffic policeman 40 years in the traffic police force and the final rank is only lance corporal whereas there are many other ranks that are available in the police structure (Ismail, Dimbap, \& Said, 2017). This shows how hard it is for a traffic police officer to get a promotion. Furthermore, salary adjustment is small and is not in line with the amount of effort for each daily work assignment. There is also a low of esteem rewards since there is lack respect between one another. For example, when it comes to recognizing the effort done, reward wise is given more to enforcement team instead of point duty units regardless of the heavy workload they carry (Liberman, Kopelowicz, Ventura, \& Gutkind). Whenever the bosses fail to appreciate their staff, this would create a stressful working environment for their employees (Allisey et al., 2016). Thus, the purpose of this study is to investigate factors that influence job stress of police traffic officers particularly in Malaysia. This study aims to determine any significant relationship between three factors of workload, work-life balance, and reward system towards dependent variable of job stress.

\section{Literature Review}

\subsection{Job Stress}

Job stress means stress related to one's job (Violanti et al., 2017). It often comes from unexpected responsibilities and pressures that do not align with a person's knowledge, skills, or expectations, inhibiting one's ability to cope. According to Poon et al. (2013), prolonged job stress might cause job burnout, which could lead to accidents that negatively impact on the organization in the form of lost working days and increased project cost. Wahab (2010) stated that continuous stress has a negative impact on a worker's health and causes some medical conditions such as high blood pressure, stomach disorders, heart attacks, sleep disturbances, headaches, back pain, skin problems and others. Arshadi and Damiri (2013) found that there was a positive relationship between job stress and turnover intention. This is due to many factors such as unstable, unsecured work environment and stress at work and lead to high turnover. Manager creates a stressful environment for their employees when they gave out tasks to employees in which the tasks were not under the employees' job scope. Applebaum et al. (2010) added that the environmental factors in term of odour, noise, light and colour would also affect job stress among their respondents of study i.e. nurses.

What may be the cause or factors that contribute to stress or stress predictor? Fernet et al. (2012) concluded that role conflict and role ambiguity might lead to stress which eventually contributes to job burnout. Role ambiguity means role uncertainty or insufficient information concerning powers, authority and duties to perform one's role. Role conflict is when supervisors and subordinates place contradictory demands on individual (Au \& Ahmed, 2016). Personnel who had a low degree of participation in decision-making and solving problems could experience stress (Ibem et al., 2011). Furthermore, poor relationships between workers at various organizational levels and senior management were one of the most important factors that led to stress and burnout (Leung, Chan, \& Dongyu, 2011). Factors causing one employee to feel stress at work could come from a lot of angle. For the purpose of this study, the researchers are looking at 3 possible ones causing work stress or job stress namely the workload itself, the work-life balance which is nature of the work itself and finally the rewards received or the reward system.

\subsection{Workload}

Excessive workload is a source of stress at work Baka (2015) and of emotional exhaustion (Karatepe, 2013). The quantity of errands (quantitative) or the trouble of assignments (subjective) can be expanded to increase the workload and accordingly to increase the level of worker employment stretch or stress. A number of researchers have supported a positive relationship between workload, stress and turnover intention (Deery \& Jago, 2015). Other than high turnover of employees, the outcome of workload also caused the employee to make more mistakes; number of absent days is much higher and experience poorer health. Employees in the services industry often have a heavy workload (Mansour \& Tremblay, 2016), have long and irregular working hours (Zhao, Lynch, \& Chen, 2010) and experience difficulty in reconciling work and family life (Choi et al., 2012)], which translates into stress at work (Kim et al., 2001). Thus, the 
hypothesis concluded is $H 1$ : There is a positive relationship between workload and job stress.

\subsection{Work-Life Balance}

Work-life balance is a concept including proper prioritizing between "work" (career and ambition) and "lifestyle" (health, pleasure, leisure, family and spiritual development/meditation) (Abendroth \& Den Dulk, 2011). This is related to the idea of lifestyle choice. A balance between work and life outside work is indeed a measure of stress level for employee at work. Work -life balance is where there is a proper prioritization of work and lifestyle. That is, a negative work-life balance will lead to stress (Deer \& Jago, 2015). Work-life balance involves multiple parties such as family support, the nature of work, and the people from workplace such as colleague, supervisor, superiors and management level. Violanti et.al. (2017) mentioned that social support from family, friends and spouses may lower the degree of stress. Thus, social support from supervisor, family and friends reduces the work-life imbalance predominantly for women. Therefore, the imbalance between employee's work and life domains would enlarge that person's job stress level. Thus, the hypothesis concluded is $H 2$ : There is negative relationship between work-life balance and job stress.

\subsection{Reward System}

Reward system is one of the most well-known job stress frameworks and has been utilized to assess and alter potentially damaging working environments Allisey et al., 2016). Shields et al. (2015) suggests that a reasonable reward system will motivate individuals so that they perform at high levels, feel secure and know that continuous learning and career advancement are valued and encouraged. The components of a reward system are esteem, status, and security rewards. Esteem reward here is employee looking for a balance in their workplace by amount of respect he/she is experiencing at work. This interaction involves colleague, superiors and the work he/she has done. Whether ample recognition is given and that he/she receives the support that is required. Second, status reward refers to with the amount of work or responsibility the employee is taking on, whether this commensurate with the salary he/she is earning (Allisey et al., 2016). Status reward is more on monetary term, whereby employee often felt that their background for example education level must carry a weight with his/her position or line of duty. Besides this, the effort given must be rewarded monetarily ample and adequate. The third point in reward system is security reward. Security reward here is not referring to how safe the job is but how secure is the job to the employee. For example, the job he/she is carrying must come with a package or incentive that secures the job for him/her. Whenever there is a sense of security embedded in the job itself this is expected to lower stress level in working environment. The effects of lack in reward system are plenty. Besides employees feeling too stress out at work, they also felt demotivated, not happy and absenteeism rate moves higher. The constant deficiencies in appropriate reward shall impair successful self-regulation and the imbalance may lead to adverse physical and psychological health effects in the long run (Siegrist \& Wahrendorf, 2009). This could prove that reward system is correlated with stress thus making the third hypothesis as $H 3$ : There is a negative relationship between reward system and job stress.

\section{Research Framework}

Based on the literature review, the following research framework is formulated. This study is also based on underpinning theory of 'Biopsychosocial Model of Stress' (Bernard \& Krupat, 1994).

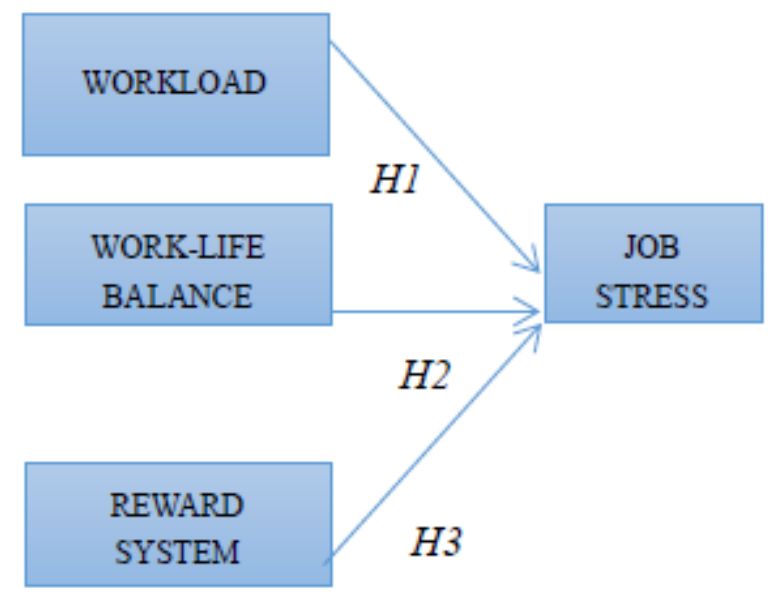

Figure 1. Research framework 


\section{Methodology}

This study is a quantitative research carried out by using cross-sectional survey method and hypothesis testing. The unit of analysis is individuals who are traffic police officers located Klang Valley, Malaysia as this area is the main capital of Malaysia hence representing the majority of police personnel in the country. A total of 300 questionnaires were distributed and 100 questionnaires are returned using quota sampling technique through self-administered questionnaire. Hair et al. (2010) recommended 100 sample size is acceptable. The measurements for each independent variable and dependent variable of this study were adapted from previous studies using Five-Point Likert scale, ranges from strongly disagree to strongly agree accordingly, that is, Strongly Disagree $=1$, Disagree $=2$, Neutral $=3$, Agree $=$ 4, Strongly Agree $=5$. The nine items of workload were adopted from Karasek (1998). Sample item include "My job requires working very fast" and "My job is very hectic". The seven items of work-life balance were adopted from Omar and Zakaria (2015). Sample item include "I am successful in balancing my work and non-work life." and "I am satisfied with my ability to balance the needs of my job with those of my non-work life". The eleven items of reward system were adopted from Siegrist and Wahrendorf (1994). Sample item include "I am treated unfairly at work" and "My position reflects education and training". The eight items of job stress were adopted from Lemyre and Tessier (2003). Sample item include "I feel stressed" and "I feel confused; my thoughts are muddled; I lack concentration; I cannot focus". Data was collected in the month of January 2017 and was analyzed using Package for Social Science (SPSS) Version 21 software program, which is required to run the multiple regression analysis.

\section{Findings and Discussion}

The respondents of this study i.e. 100 Malaysian traffic police officers were mainly males (88\%), aged between 21 to 30 years old $(42 \%)$, Malay $(91 \%)$, married $(71 \%)$, ranked as corporal $(44 \%)$, having secondary school education $(67 \%)$, and having one to three children (49\%). As per Table 1, the results showed that Cronbach's Alpha values for all the variables used in the questionnaire are greater or almost equal to $0.60(\alpha \geq 0.60)$, indicating that the questionnaire had fulfilled the minimum internal consistency reliability (Loewenthal, 2004). Table 1 also shows that the level of workload and work-life were quite high and the levels of reward system job stress were moderate among the traffic police officer under study. Surprisingly the moderate level of job stress among the respondents was consistent with a quite high, meaning in average the traffic police were agreeing that they were enjoying quite a balanced equilibrium between their work and non-work lives although at the same they were agreeing of having to do quite a high workload.

Table 1. Descriptive and reliability analysis for all variables

\begin{tabular}{lccc}
\hline Variables & Mean & Std Deviation & Cronbach's Alpha \\
\hline Workload & 3.4222 & .46928 & .554 \\
Work-life & 3.5643 & .69879 & .926 \\
balance & & & \\
Reward & 3.2455 & .46400 & .652 \\
system & 3.1000 & .61827 & .672 \\
\hline
\end{tabular}

According to Table 2, the model explains that there is approximately $10.5 \%\left(\mathrm{R}^{2}=0.105\right)$ of the variance in the job stress of Malaysian traffic police officers due to all three independent factors. This small percentage of variation could be because of only one variable that is significant as predictor of job stress. Since the F value was significant at $\mathrm{p}=0.013$, therefore the conclusion is that all independent variables have significant influences on the job stress. According to Table 2, the coefficients of each factor that contributed to the predicted scores using the equation of model as below.

$$
\mathrm{B} 4=2.971+0.298(\mathrm{~B} 1)-0.495(\mathrm{~B} 2)+0.181(\mathrm{~B} 3)
$$

Where:

$$
\begin{aligned}
& \text { B1 }=\text { Workload } \\
& \text { B2 }=\text { Work-Life Balance } \\
& \text { B3 }=\text { Reward System } \\
& \text { B4 }=\text { Job Stress }
\end{aligned}
$$


Based on the results shown in Table 2, the significant values (Sig.) of only one of the three independent variables (i.e. work-life balance instead of workload and reward system) that was less than 0.05 . This indicates that only one of predictor variables in the model that have significant impacts on the job stress. In summary based on Table 2, there were no relationships between workload and job stress as well as between reward system and job stress. Therefore, $\mathrm{H} 1$ and $\mathrm{H} 3$ were not supported and $\mathrm{H} 0$ for both relationships were accepted. However, there was a significant and negative relationship between work-life balance and job stress. Therefore, $\mathrm{H} 2$ was supported and $\mathrm{H} 0$ was rejected. This finding is consistent with the study from Violanti et.al. who studied the stress situation among police officers in United States, which explained that a negative work-life balance will lead to stress. This study therefore provides additional evidence to all academic and practitioners on the effects of work-life balance, thus appropriate policies and management strategies can be undertaken to ensure a stress-free working environment.

Table 2. Multiple Regression Analysis

\begin{tabular}{|c|c|c|c|c|c|c|}
\hline \multirow[t]{2}{*}{ Model } & & \multicolumn{2}{|c|}{$\begin{array}{c}\text { Unstandardized } \\
\text { Coefficients }\end{array}$} & \multirow{2}{*}{$\begin{array}{c}\text { Standardized } \\
\text { Coefficients }\end{array}$} & \multirow[t]{2}{*}{$\mathrm{t}$} & \multirow[t]{2}{*}{ Sig. } \\
\hline & & B & $\begin{array}{l}\text { Std. } \\
\text { Error }\end{array}$ & & & \\
\hline (Constant) & & 2.97 & .71 & & 4.17 & .00 \\
\hline Workload & & .29 & .20 & .163 & 1.50 & .14 \\
\hline Work-Life Balance & & -.50 & .16 & -.404 & -3.1 & .00 \\
\hline Reward System & & .18 & .24 & .098 & .76 & .45 \\
\hline F value & 3.761 & & & & & \\
\hline Sig & .013 & & & & & \\
\hline Adjusted $\mathrm{R}^{2}$ & .077 & & & & & \\
\hline $\mathrm{R}^{2}$ & .105 & & & & & \\
\hline
\end{tabular}

\section{Conclusion}

In conclusion, this study found that workload and reward system were not the significant factors for employees' job stress among traffic police officers particularly in Malaysia. Nonetheless it was the feelings of equilibrium between an employee's work and life domains that would be the significant factor for employee's job stress especially among Malaysia traffic police officers. Therefore, it is important for the management of traffic police officers to take into consideration in ensuring their personnel would enjoy the balance in both of their work and life demands as this could negatively related to their job stress. The more the traffic police officers enjoying a work-life balance, the less they will feel stressful in their job. Hence, the police policy makers should implement any work-life balance practices such as flexible work arrangements or work-life benefits as to promote a healthy workplace for their employees psychologically, physiologically and physically. However, the generalization of this study could be limited to the sample of this study. Therefore, it is suggested that future studies to replicate similar research framework using different sample such as in other states and countries.

\section{Acknowledgment}

This research was funded by Universiti Teknologi MARA, Malaysia (Grant No: 600-IRMI/Dana KCM 5/3/LESTARI (201/2017).

\section{References}

Abendroth, A., \& Den Dulk, L. (2011). Support for the work-life balance in Europe: the impact of state, workplace, and family support on work-life balance satisfaction. Work, Employment and Society, 25(2), 234-256. https://doi.org/10.1177/0950017011398892

Allisey, A., Rodwell, J., \& Noblet, A. (2016). An application of an extended effort-reward imbalance model to police absenteeism behavior. Personnel Review, 45(4), 663-680. https://doi.org/10.1108/PR-06-2014-0125

Applebaum, D., Fowler, S., Fiedler, N., Osinubi, O., \& Robson, M. (2010). The Impact of Environmental Factors on Nursing Stress, Job Satisfaction, and Turnover Intention. Journal of Nursing Administration, 40(0), 323-328. https://doi.org/10.1097/NNA.0b013e3181e9393b 
Arshadi, N., \& Damiri, H. (2003). The Relationship of Job Stress with Turnover Intention and Job Performance: Moderating Role of OBSE. Procedia - Social and Behavioral Sciences, 84(2003), 706-710. https://doi.org/10.1016/j.sbspro.2013.06.631

Au, W. C., \& Ahmed, P. K. (2016). Relationships between superior support, work role stressors and work-life experience. Personnel Review, 45(4), 782-803. https://doi.org/10.1108/PR-08-2014-0175

Baka, L. (2015). The effects of job demand on mental and physical health in the group of police officers. Testing the mediating role of job burnout. Studia Psychologica, 57(4), 285.

Bernard, L. C., \& Krupat, E. (1994). Health psychology: Biopsychosocial factors in health and illness. Orlando, FL, US: Harcourt Brace College Publishers.

Choi, Y., Kim, Y. S., Pekelnicky, D. D., \& Kim, H. J. (2012). Preservation and modification of culture in family socialization: Development of parenting measures for Korean immigrant families. Asian American Journal of Psychology, 4(2), 143-154. https://doi.org/10.1037/a0028772

Deery, M., \& Jago, L. (2015). Revisiting talent management, work-life balance and retention strategies. International Journal of Contemporary Hospitality Management, 27(3), 453-472.

Fernet, C., Guay, F., Senécal, C., \& Austin, S. (2012). Predicting intra individual changes in teacher burnout: The role of perceived school environment and motivational factors. Teaching and Teacher Education, 28(4), 514-525.

Hair, J. F., Black, W. C., Babin, B. J., \& Anderson, R. E. (2010). Multivariate Data Analysis (7th ed.). Prentice Hall, Upper Saddle River, New Jersey.

Ibem, E. O., Anosike, M. N., Azuh, D. E., \& Mosaku, T. O. (2011). Work stress among Professionals in the Building Construction Industry in Nigeria. Australasian Journal of Construction Economics and Building, 11(3), 45-57.

Ismail, A. M., Dimbap, D. S. A., \& Said, J. (2017). Mapping enforcement agency integrity: evidence from the Royal Malaysian Police (RMP). Journal of Management and Marketing Review, 2(1), 15-23.

Karasek, R. A. (2015). The new work organization, conducive production, and work quality policy. In M. Marmot (Ed.), Labor market changes and job insecurity: A challenge for social wellfare and health promotion (pp. 78-105, 1998). Copenhagen: WHO/Europe.

Karatepe, O. M. (2013). High-performance work practices, work social support and their effects on job embeddedness and turnover intentions. International Journal of Contemporary Hospitality Management, 25(6), 903-921.

Kim, J. J., Lee, H. J., Han, J. S., \& Packard, M. G. (2001). Amygdala is critical for stress-induced modulation of hippocampal long-term potentiation and learning. J Neurosci, 21, 5222-5228.

Lemyre, L., \& Tessier, R. (2003). Measuring psychological stress. Concept, model, and measurement instrument in primary care research. Can Fam Physician, 49, 1159-60-1166-8.

Leung, M., Chan, Y. S. I., \& Dongyu, C. (2011). Structural linear relationships between job stress, burnout, physiological stress, and performance of construction project managers. Engineering, Construction and Architectural Management, 18(3), 312-328.

Liberman, R. P., Kopelowicz, A., Ventura, J., \& Gutkind, D. (2002). Operational criteria and factors related to recovery from schizophrenia. International Review of Psychiatry, 14(4), 256-272. https://doi.org/10.1080/0954026021000016905

Loewenthal, K. M. (2004). An introduction to psychological tests and scale (2nd ed.). Hove, 2004, UK: Psychology Press.

Mansour, S., \& Tremblay, D. G. (2016). Workload, Generic and Work-family Specific Social Supports and Job Stress. International Journal of Contemporary Hospitality Management, 28(8), 1778-1804.

Noblet, A. J., Rodwell, J. J., \& Allisey, A. F. (2009). Police stress: the role of the psychological contract and perceptions of fairness. Policing: An International Journal of Police Strategies \& Management, 32(4), 613-630.

Omar, M. K., \& Zakaria, A. (2015). Conseptualising work-life balance; Extension of work-family balance. Advanced Science Letters, 21(6), 2155-2158. https://doi.org/10.1166/asl.2015.6240 
Poon, S. W., Rowlinson, S. M., Koh, T., \& Deng, Y. (2013). Job burnout and safety performance in the Hong Kong construction industry. International Journal of Construction Management, 13(1), 69-78.

Shields, J., Brown, M., Kaine, S., Dolle-Samuel, C., North-Samardzic, A., McLean, P., ... Plimmer, G. (2015). Managing Employee Performance \& Reward: Concepts, Practices, Strategies. Cambridge University Press.

Siegrist, J., \& Wahrendorf, M. (2009). Quality of work, health, and retirement. The Lancet, 374, 1872-1873.

Violanti, J. M., Charles, L. E., McCanlies, E., Hartley, T. A., Baughman, P., Andrew, M. E., ... Burchfiel, C. M. (2017). Police stressors and health: a state-of-the-art review. Policing: An International Journal of Police Strategies \& Management, 40(4), 642-656.

Wahab, A. B. (2010). Stress management among artisans in construction industry in Nigeria. Global Journal of Researches in Engineering, 10(1), 93-103.

Zhao, X., Lynch, J. J. G., \& Chen, Q. (2010). Reconsidering Baron and Kenny: Myths and truths about mediation analysis. Journal of Consumer Research, 37(2), 197-206. 